\title{
FAKTOR-FAKTOR YANG MEMPENGARUHI KECEMASAN PADA IBU SAAT MENGHADAPI HOSPITALISASI PADA ANAK DI RUANG ANAK RSUD PARE KEDIRI TAHUN 2008
}

\section{Factors That Influence Anxiety of Mothers With Childrens Hospitalization In Pediatric Room Rsud Pare Kediri 2008}

\author{
Anas Tamsuri ${ }^{1}$, Helena Lenawati ${ }^{2}$, Hendrit Puspitasari $^{3}$ \\ ${ }^{1)}$ Akademi Keperawatan Pamenang Pare \\ Jl. Soekarno Hatta No 1 Pelem Pare Kediri 64211 \\ ${ }^{2,3}$ Rumah Sakit Umum Daerah Pare \\ Jl. PK. Bangsa Pare Kediri \\ ${ }^{1)}$ e-mail: anastamsuri@gmail.com
}

\begin{abstract}
ABSTRAK
Pada saat anak mengalami hospitalisasi, orang tua dapat mengalami kecemasan yang pada akhirnya dapat mengganggu individu ibu sendiri maupun menyebabkan proses perawatan pada anak menjadi tidak optimal. Tujuan dari penelitian adalah untuk mengetahui apakah faktor pengalaman, pengetahuan dan dukungan sosial keluarga berpengaruh terhadap kecemasan ibu dalam menghadapi hospitalisasi pada anak. Desain yang digunakan dalam penelitian ini adalah analytic cross sectional, sampel diambil dari ibu-ibu yang sedang menunggu anaknya yang sakit di ruang anak RSUD Pare Kediri sejumlah 32 orang yang dipilih secara acak. Pengambilan data dilakukan dengan kuesioner selama Januari dan Februari 2008. Analisis dilakukan dengan uji regresi berganda dengan á = 0,05. Hasil dari penelitian menunjukkan pengalaman dan dukungan sosial berpengaruh terhadap kecemasan ibu sedangkan pengetahuan tidak berpengaruh secara signifikan terhadap kejadian kecemasan. Persamaan regresi hasil pengujian tidak memenuhi asumsi klasik sehingga model regresi belum layak untuk dijadikan kesimpulan penelitian. Dari hasil penelitian disarankan agar perawat dapat memberikan informasi sebagai upaya meningkatkan pengetahuan sekaligus sebagai dukungan sosial serta disarankan ada penelitian lebih lanjut yang mampu memberikan hasil penelitian yang lebih baik.
\end{abstract}

Kata kunci: pengalaman, pengetahuan, dukungan sosial, kecemasan, hospitalisasi

\section{ABSTRACT}

While child hospitalizing, parents may experienced anxiety which may affect to themselves or cause the quality of care for their child is not adequate. The objectives of this research was to explore are experience, knowledge and social support has influence to level of anxiety of the mother while their child was being hospitalized. Research design was analytic cross sectional. Sample was mother which accompanied their child in Pare Kediri Hospital as 32 persons and chosen randomly. Data was taken by question list on January-February 2008. Data was analyzed by regression test with á =0,05. Study result was there was significant influence of experience and knowledge due to anxiety and that knowledge didn't significantly influence anxiety. Regression formula was not meet the classic assumption due to the model can't figured as the result of research. From research, it is suggested for nurse to give appropriate information as an effort to increase mother's knowledge and as a kind of social support and it's suggested for further research in this field for better result.

Keywords: experience, knowledge, social support, anxiety, hospitalization

\section{LATAR BELAKANG}

Hospitalisasi merupakan suatu proses yang karena suatu alasan yang berencana atau darurat, mengharuskan anak untuk tinggal di rumah sakit, menjalani terapi dan perawatan sampai pemulangannya kembali ke rumah (Supartini, 2004). Selama proses 
hospitalisasi, anak dan orang tua dapat mengalami berbagai kejadian yang menurut beberapa penelitian ditunjukkan dengan pengalaman yang sangat traumatik dan penuh dengan stres. Berbagai perasaan yang sering muncul pada anak yaitu cemas, marah, sedih, takut dan rasa bersalah (Wong, 2000 dalam Supartini, 2004).

Hospitalisasi yang terjadi pada anak merupakan pengalaman yang mengganggu kehidupan anak yang dapat juga menyebabkan kecemasan pada orang tua (Brewis, 1995 dalam Supartini, 2004). Orang tua akan mengalami kekhawatiran akan terjadinya sesuatu yang menyakitkan atau menyebabkan penderitaan pada anak. Stres akibat hospitalisasi akan menimbulkan perasaan tidak nyaman pada anak maupun pada keluarga. Reaksi kecemasan pada anak dapat timbul karena perpisahan, kehilangan, perlukaan tubuh dan rasa nyeri sedangkan orang tua mengalami perasaan cemas, takut, sedih dan frustasi. Perasaan tersebut dapat timbul karena menghadapi sesuatu yang baru dan belum pernah dialami sebelumnya, rasa tidak aman dan tidak nyaman, perasaan kehilangan sesuatu yang biasa, dan sesuatu yang dirasakan menyakitkan. Tidak hanya anak, orang tua juga mengalami hal yang sama. Apabila anak stres selama dalam perawatan orang tua menjadi stres pula, dan stres orang tua akan membuat tingkat stres anak semakin meningkat.

Sebagai salah satu anggota tim kesehatan, perawat memegang posisi kunci untuk membantu orang tua menghadapi pemasalahan yang berkaitan dengan perawatan anaknya di rumah sakit karena perawat berada di samping pasien selama 24 jam dan fokus asuhan adalah peningkatan kesehatan anak melalui pemberdayaan keluarga. Untuk itu, berkaitan dengan upaya mengatasi masalah yang timbul baik pada anak maupun orang tua selama anaknya dalam perawatan di rumah sakit, fokus intervensi keperawatan adalah meminimalkan stresor, memaksimalkan manfaat hospitalisasi, memberikan dukungan psikologis pada anggota keluarga, dan mempersiapkan anak sebelum dirawat di rumah sakit. Dengan demikian asuhan keperawatan tidak bisa hanya berfokus pada anak tetapi juga pada orang tua. Individu dengan gangguan ansietas atau cemas mengalami gejala-gejala fisiologik, kognitif dan perilaku ansietas (Isaacs, 2004).

\section{METODE}

Jenis penelitian termasuk kuantitatif dengan pendekatan observasional. Desain dalam penelitian menggunakan cross sectional. Variabel dependen penelitian ini adalah kecemasan sementara variabel independen adalah pengalaman hospitalisasi, pengetahuan dan dukungan sosial. Penelitian dilakukan di ruang anak RSUD Pare Kediri selama periode 1 bulan dengan asumsi responden sejumlah 49 orang. Sample yang digunakan dalam penelitian sejumlah $32 \mathrm{ibu}$ yang dipilih secara acak atau randomized sampling. Pengambilan data dilakukan dengan menggunakan kuesioner penelitian sedangkan analisis data dilakukan dengan menggunakan uji regresi berganda dengan á $=0,05$.

\section{HASIL DAN PEMBAHASAN}

\section{Hasil}

\section{Karakteristik Responden Berdasarkan Pendidikan}

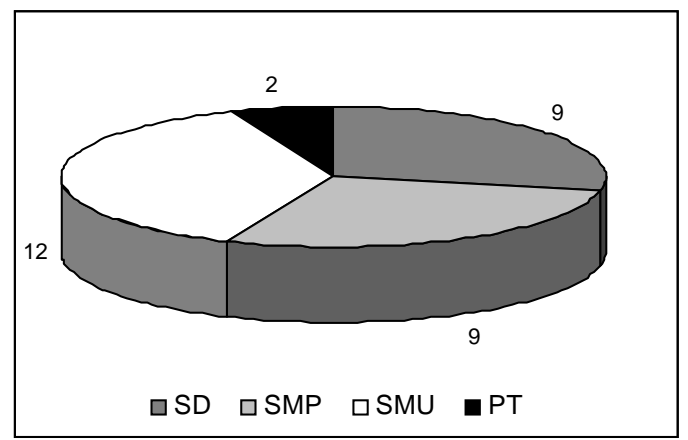

Gambar 1. Diagram karakteristik responden berdasarkan pendidikan di ruang anak RSUD Pare Kediri tahun 2008 


\section{Karakteristik Responden Berdasarkan Pekerjaan}

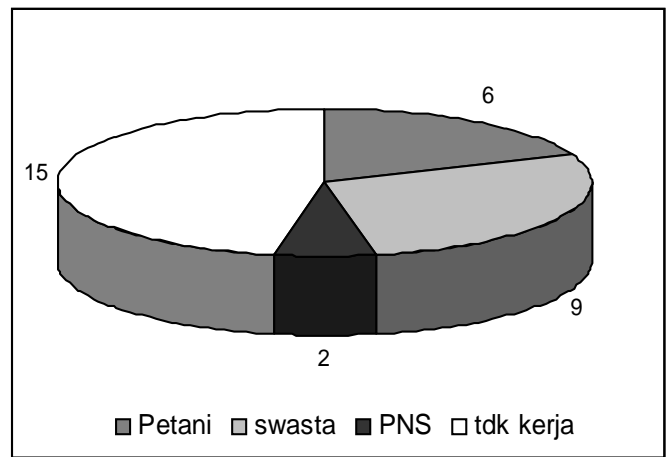

Gambar 2. Diagram karakteristik responden berdasarkan pekerjaan di ruang anak RSUD Pare Kediri tahun 2008

\section{Karakteristik Responden Berdasarkan} Umur

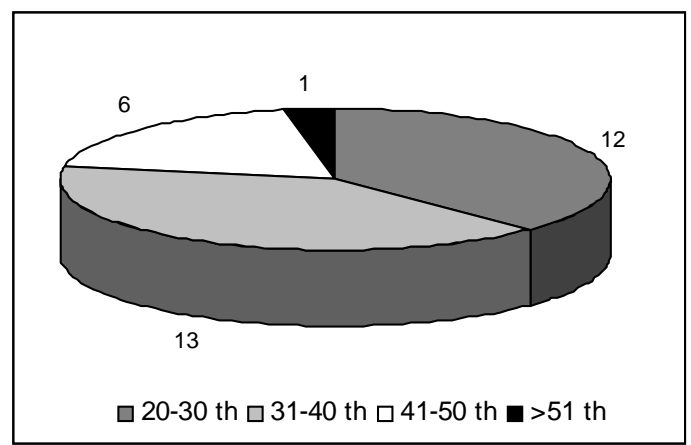

Gambar 3. Diagram karakteristik responden berdasarkan kelompok umur di ruang anak RSUD Pare Kediri tahun 2008

\section{Karakteristik Responden Berdasarkan Jumlah Anak}

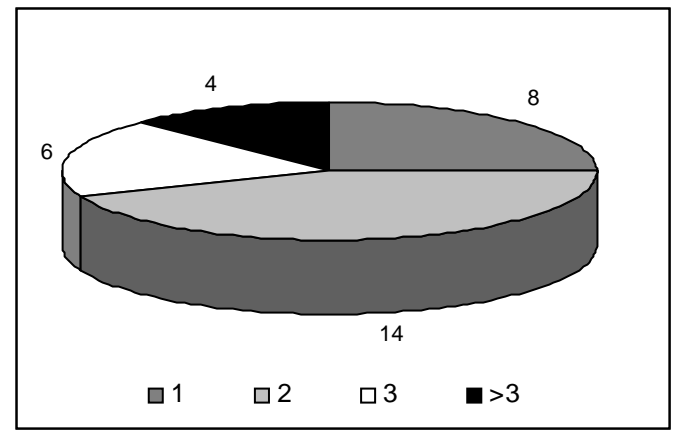

Gambar 4. Diagram karakteristik responden berdasarkan jumlah anak di ruang anak RSUD Pare Kediri tahun 2008

\section{Karakteristik Responden Berdasarkan Pengalaman}

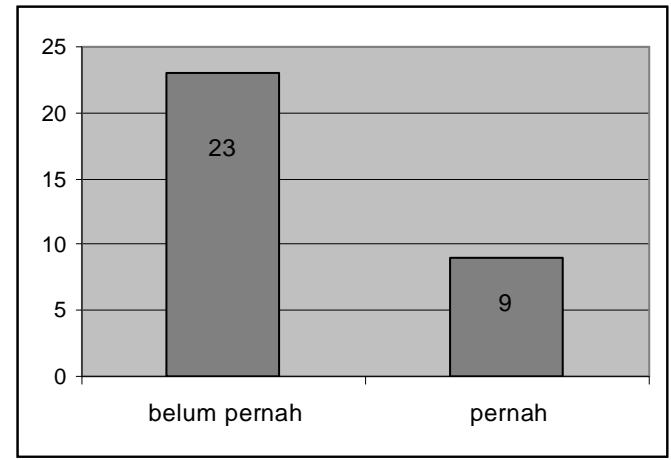

Gambar 5. Grafik karakteristik responden berdasarkan pengalaman di ruang anak RSUD Pare Kediri tahun 2008

\section{Pengetahuan, Dukungan Sosial Dan Tingkat Kecemasan Responden}

Tabel 1. Pengetahuan responden tentang hospitalisasi

\begin{tabular}{ccccc}
\hline VARIABEL & $\begin{array}{c}\text { Standar } \\
\text { deviasi }\end{array}$ & $\begin{array}{c}\text { Rata-rata } \\
\text { nilai }\end{array}$ & $\begin{array}{c}\text { Nilai } \\
\text { minimum }\end{array}$ & $\begin{array}{c}\text { Nilai } \\
\text { maksimum }\end{array}$ \\
\hline Pengetahuan & 1,92 & 6,53 & 3 & 10 \\
Dukungan Sosial & 3,41 & 14,78 & 9 & 20 \\
Kecemasan & 4,80 & 16,28 & 9 & 28 \\
\hline
\end{tabular}

Pengaruh pengalaman, pengetahuan dan dukungan sosial terhadap kecemasan ditentukan dengan menggunakan uji korelasi berganda dengan á $=0,05$. Hasil uji dengan menggunakan program komputer didapatkan sebagai berikut:

Tabel 2. Model summary ${ }^{\mathrm{b}}$

\begin{tabular}{|c|c|c|}
\hline & & $\begin{array}{c}\text { Model } \\
1\end{array}$ \\
\hline$R$ & & $0,793^{\mathrm{a}}$ \\
\hline$R$ Square & & 0,629 \\
\hline $\begin{array}{l}\text { Adjusted } \\
\text { Square }\end{array}$ & $R$ & 0,589 \\
\hline
\end{tabular}




\begin{tabular}{lr}
\hline Std. Error of the r & 3,07627 \\
Estimate & \\
Durbin-Watson & 1,714
\end{tabular}

Keterangan:

- Predictors: (constant), dukungan sosial, pengetahuan, pengalaman

- Dependent variable: kecemasan=

Tabel 3. ANOVA

\begin{tabular}{lccc}
\hline & \multicolumn{3}{c}{$\begin{array}{c}\text { Model } \\
\mathbf{1}\end{array}$} \\
\cline { 2 - 4 } & Regression & Residual & Total \\
\hline Sum of Squares & 449,492 & 264,976 & 714,469 \\
df & 3 & 28 & 31 \\
Mean Square & 149,831 & 9,463 & \\
F & 15,833 & & \\
Sig. & $0,000^{\mathrm{a}}$ & & \\
\hline
\end{tabular}

Keterangan:

- Dependent variable: kecemasan

- Predictors: (constant), dukungan

sosial, pengetahuan, pengalaman

Tabel 2. Coefficients ${ }^{\mathrm{a}}$

\begin{tabular}{lcccccc}
\hline Model & \multicolumn{2}{c}{$\begin{array}{c}\text { Unstandardized } \\
\text { Coefficients }\end{array}$} & $\begin{array}{c}\text { Standardized } \\
\text { Coefficients }\end{array}$ & & \\
\cline { 2 - 7 } & $\boldsymbol{B}$ & Std. Error & Beta & $\boldsymbol{t}$ & Sig. \\
\hline 1 & (Constants) & 17,911 & 4,548 & & 3,939 & 0,000 \\
& Pengalaman & 5,415 & 1,465 & 0,515 & 3,697 & 0,001 \\
& Pengetahuan & $-0,260$ & 0,321 & $-0,104$ & $-0,811$ & 0,424 \\
Dukungan sosial & $-0,465$ & 0,194 & $-0,330$ & $-2,394$ & 0,024 \\
\hline
\end{tabular}

Keterangan:

\section{Dependent variable: kecemasan}

Perhitungan regresi didapatkan nilai $\mathrm{R}^{2}$ (koefisien determinasi) yang merupakan prediktor seberapa besar varian dan variabel dependen dapat dijelaskan oleh variasi variabel-variabel independen sebesar 0,629. Hal ini bermakna bahwa pengetahuan, pengalaman dan dukungan sosial hanya mampu memberikan kontribusi atau memprediksi adanya kecemasan sebanyak $62,9 \%$ dan sisanya $37,1 \%$ dipengaruhi atau dijelaskan oleh variabel lain di luar variabel yang diteliti.

Uji $F$ untuk mengetahui proporsi variabel dependen yang dijelaskan variabel independen secara serempak. Nilai uji $\mathrm{F}$ adalah 15,833 dengan signifikansi 0,000 yang berarti memang variabel independen secara bersama-sama mempengaruhi variabel dependen.
Dari kedua prediktor kasar dilanjutkan dengan uji $t$ untuk menunjukkan kebermaknaan fungsi atau pengaruh masingmasing variabel bebas. Hasil uji $t$ menunjukkan signifikansi variabel pengalaman, pengetahuan, dukungan sosial terhadap kecemasan ibu berturut-turut adalah: 0,$001 ; 0,424$ dan 0,024 .

Hasil menunjukkan bahwa pengetahuan kurang memiliki pengaruh kepada terjadinya kecemasan pada ibu pasien. Persamaan regresi dari hasil perhitungan statistik adalah sebagai berikut: kecemasan $=5,415$ (pengalaman) - 0,260 (pengetahuan) - 0,465 (dukungan sosial) $+17,911+\mathrm{e}$

\section{Pembahasan}

Berdasarkan hasil penelitian didapatkan bahwa ternyata faktor pengalaman dan dukungan sosial sangat berpengaruh terhadap tingkat kecemasan (sig. 0,000 \& sig 0,024) 
sedangkan faktor pengetahuan kurang berpengaruh terhadap kecemasan ( $s i g$. $0,424)$.

Menurut Ann Isaacs, kecemasan adalah keprihatinan, kesulitan, ketidakpastian dan ketakutan yang terjadi akibat ancaman yang nyata. Menurut Brewis (1995) dalam Supartini (2004) disebutkan bahwa anak adalah bagian dari kehidupan orang tuanya sehingga bila ada pengalaman yang mengganggu kehidupannya maka orang tua akan merasa cemas, dalam hal ini orang tua akan mengalami kecemasan yang tinggi saat perawatan anaknya di rumah sakit walaupun beberapa orang tua tidak mengalami hal tersebut. Kejadian kecemasan pada orang tua telah diteliti oleh beberapa peneliti seperti dari Wahyuningsih (2008) yang mendapatkan terdapat sekitar sebagian kecil (6\%) responden tidak mengalami kecemasan, hampir setengahnya (32\%) responden mengalami cemas ringan, sebagian besar (62\%) responden mengalami cemas sedang, dan tidak satupun $(0 \%)$ responden mengalami cemas berat. Penelitian dari Alexander (1997) menunjukkan dari studi terhadap 51 pasien yang tidak tidur sekamar dengan anak yang dirawat dengan menggunakan spielberger state trait inventory didapatkan adanya tingkat kecemasan yang lebih tinggi pada orang tua, terutama pada mereka yang memiliki jumlah anak yang lebih banyak dirumah, kurang pendidikan serta memiliki status sosial yang lebih rendah. Tingkat kecemasan juga terjadi lebih tinggi pada bapak dibandingkan pada ibu karena mereka cenderung mempertahankan perasaan cemas, serta adanya kenyataan bahwa semakin jarang mereka menemui anak maka tingkat kecemasan yang dirasakan oleh orang tua semakin meningkat. Menurut Hudak dan Gallo (1997) kecemasan dapat muncul bila ada ancaman ketidakberdayan menghadapi situasi tertentu serta kehilangan kendali atau kontrol terhadap diri dan lingkungan. Pada keluarga yang anaknya mengalami hospitalisasi maka mereka dapat saja mengalami kecemasan karena mereka mendapati anaknya sakit namun mereka tidak mampu untuk berbuat sesuatu untuk menolong kereka dan merasa tidak berdaya untuk memberikan bantuan yang dibutuhkan oleh anaknya. Pada kondisi anak harus masuk rumah sakit dan mendapati mereka diberlakukan prosedur tertentu, keluarga (orang tua) juga menghadapi ketidakberdayaan atas segenap prosedur dan tindakan yang dilakukan terhadap anaknya. Perilaku pemasangan alat-alat dan tindakan yang menyakitkan seperti dilakukannya injeksi akan membuat anak mereka menderita dan mengalami ketakutan. Ketakutan atau kecemasan yang terjadi pada anak ini pun pada akhirnya mengakibatkan mereka mengalami kecemasan. Disamping faktor ketidakberdayaan, kecemasan pada orang tua dapat muncul sebagai respon dari adanya keterasingan dengan lingkungan rumah sakit seperti tidak mengenal ruangan dan orang-orang yang berada didalamnya, tidak mengerti peraturan dan prosedur medik serta adanya perasaan tidak dapat mengontrol diri dan tidak dapat menempatkan diri untuk menentukan apa peran yang harus dilakukannya selama anak masuk rumah sakit.

Hasil penelitian menunjukkan bahwa pengalaman berpengaruh secara bermakna terhadap kecemasan. Pengalaman adalah suatu kondisi dimana seseorang pernah berada pada situasi atau kondisi yang sama sebelumnya. Pengalaman dapat muncul sebagai bentuk pernah mengalami paparan secara fisik terhadap sesuatu, atau paparan secara persepsi atau psikologis terhadap suatu kondisi atau situasi. Kegiatan hospitalisasi tidak hanya melibatkan paparan fisik semata dengan petugas maupun lingkungan rumah sakit, namun juga terjadi kondisi dimana seseorang berada pada situasi dan sistem yang tidak dapat mereka kontrol serta mengalami ketidakberdayaan. Sesuai dengan Hudak dan Gallo (1997) maka situasi seperti ini akan mempengaruhi tingkat kecemasan 
orang tua. Menurut Penelitian dari Tiedeman (1997) didapatkan bahwa terhadi penurunan tingkat kecemasan pada orang tua mulai dari saat masuk hingga masa pemulangan sementara tingkat kecemasan pada orang tua cenderung menetap dari masa pemulangan hingga masa post hospitalisasi. Penelitian Tiedeman juga menunjukkan bahwa terdapat hubungan yang positif antara kecemasan orang tua dengan lamanya anak menjalani hospitalisasi. Kondisi ini menggambarkan bahwa pengalaman orang tua selama berada di rumah sakit akan membantu mereka mengidentifikasi sumber-sumber stress dan kecemasan secara lebih obyektif sehingga kecemasan yang timbul akibat perasaan ketidakpastian dapat berkurang. Mengacu pada pendapat Post (1978) dalam Sunaryo (2004) bahwa kecemasan merupakan perasaan subyektif seperti ketegangan, ketakutan, kekhawatiran; maka dengan pengalaman yang dimiliki oleh orang tua maka mereka dapat mengurangi kekhawatiran yang mungkin timbul akibat bayangan terhadap situasi yang tidak mereka kenal sebelumnya. Peneliti berpendapat bahwa pada orang-orang yang telah pernah menghadapi situasi hospitalisasi cenderung memiliki pandangan yang lebih obyektif menghadapi hospitalisasi sehingga mereka akan memiliki pola fikir dan sudut pandang yang lebih baik dan kecemasan cenderung berkurang.

Penelitian juga menunjukkan bahwa dukungan sosial berhubungan erat dengan kecemasan. Hasil ini sesuai dengan penelitian dari Rahmawati (2008) tentang pengaruh dukungan keluarga terhadap kecemasan pada anak pra sekolah yang mengalami hospitalisasi menunjukkan bahwa terdapat hubungan yang cukup kuat antarara dukungan keluarga dengan tingkat kecemasan yang dialami oleh anak. Adanya dukungan dari lingkungan rumah sakit maupun dari keluarga serta kerabat dapat memberikan makna tersendiri bagi pasien dan anggota keluarga. Dukungan sosial adalah dukungan yang diberikan oleh lingkungan orang-orang terhadap personal atau kelompok dan sistem sebagai kelompok pendukung terhadap perilaku atau situasi yang dapat menimbulkan stres. Menurut Ball dalam Henderson (2006) bahwa dukungan sosial dapat berupa budaya peduli yang dilakukan individu satu sama lain atau dapat berupa budaya peduli yang diberikan oleh masyarakat dan layanan perawatan yang terdapat didalamnya. Caplan dalam Henderson (2006) menyatakan dukungan sosial yang efektif adalah dukungan yang memampukan individu yang stres menerima orang yang membantunya sebagai seorang sekutu, dan yang meyakinkannya bahwa ketrampilan, waktu dan pengertian orang yang membantunya tersedia selama ia membutuhkannya. Rahasia keberhasilan menjadi orang yang membantu terletak pada hubungan yang berkembang antara individu dan pemberi perawatan. Menurut Caplan sistem pendukung pasien dapat berupa keluarga, teman dan individu terdekat. Dukungan sosial menurut Dunkell-Scheffer (1987) dalam Abraham (1997) meliputi ekspresi perasaan positif, termasuk menunjukkan bahwa seseorang diperlakukan dengan rasa penghargaan yang tinggi dan atau pemberitahuan tentang ketepatan keyakinan atau perasaan seseorang. Ajakan untuk membuka diri dan mendiskusikan keyakinan dan sumber-sumber juga merupakan bentuk dukungan sosial. Dengan adanya dukungan sosial ini akan memperkuat pertahanan individu menghadapi situasi yang menimbulkan stress (stresor), adanya stres pada seseorang yang memiliki kelompok pendukung yang kuat akan menyebabkan timbulkan 'mekanisme buffer' dimana pada saat stres timbul toleransi fisik dan emosional yang lebih baik. Teman dekat jika dibutuhkan akan menjadi penyangga dalam menghadapi efek buruk stres, yaitu dengan ikut serta merasakan ketegangan yang ada (National Safety Council, 2003). Dari uraian diatas maka dapat dinyatakan bahwa memang dukungan sosial dapat mengurangi kecemasan pada keluarga pasien yang anaknya menjalani hospitalisasi. 
Hasil penelitian menunjukkan bahwa pengetahuan kurang memberikan pengaruh terhadap kecemasan. Hasil ini tidak sesuai dengan hasil penelitian dari Kurniawan (2008) yang meneliti tentang faktor-faktor yang mempengaruhi kecemasan pada orang tua terkait hospitalisasi anak. Menurut Supartini (2004) kecemasan orang tua akan meningkat jika mereka kurang informasi terutama tentang prosedur dan pengobatan anak. Begitu juga sebaliknya adanya atau banyaknya informasi yang tidak tepat atau bahkan keliru dapat menyebabkan dirinya menjadi panik dan terjadi peningkatan respons cemas. Berdasarkan pendapat dari supartini maka dapat diungkapkan bahwa pengetahuan seakan memiliki dua sisi yang saling bertolak belakang, yaitu apabila seseorang mendapatkan informasi dan memiliki pengetahuan yang baik dan obyektif akan membantu dirinya untuk mengatasi kecemasan atau ketakutan yang dimilikinya, namun disisi lain manakala seseorang memiliki banyak pengetahuan namun berisi hal-hal yang bersifat negatif maka dapat menyebabkan mereka mengalami kecemasan yang semakin besar.

\section{KESIMPULAN DAN SARAN}

Berdasarkan pembahasan disimpulkan bahwa terdapat pengaruh yang signifikan antara pengalaman dan dukungan keluarga terhadap terjadinya kecemasan, pengetahuan kurang berpengaruh secara signifikan terhadap terjadinya kecemasan pada ibu dengan anak hospitalisasi

Saran yang dapat diberikan kepada perawat yaitu agar dapat memberikan perhatian lebih kepada ibu yang anaknya mengalami hospitalisasi, terutama bagi mereka yang memiliki pengalaman minim tentang pelayanan rumah sakit. Diharapkan agar perawat dapat secara proaktif memberikan informasi yang obyektif kepada ibu atau keluarga sehingga mereka mendapatkan informasi yang benar sekaligus memperoleh perhatian dan dukungan sosial dari perawat. Perawat juga diharapkan memberikan kesempatan kepada keluarga untuk mendapat dukungan sosial dari anggota lainnya. Dari hasil penelitian ini, diharapkan ada penelitian lebih lanjut tentang faktor yang mempengaruhi kecemasan sehingga dapat disusun suatu model regresi yang lebih baik.

\section{DAFTAR PUSTAKA}

Abraham, C., Shanley, E. 1997. Psikologi Sosial Untuk Perawa. Jakarta: EGC.

Alexander, D., et. al. 1986. Anxiety of NonRooming-In Parents of Hospitalized Children. journal Children's Health Care. Volume 15. Issue 1 June 1986.

Arikunto, S. 1998. Prosedur Penelitian Suatu Pendekatan Praktek. Jakarta: EGC.

Henderson, C. et. al. 2001. Buku Ajar Konsep Kebidanan. Jakarta: EGC.

Hudak \& Gallo. 1997. Keperawatan Kritis. Jakarta: EGC.

Isaacs, A. 2004. Keperawatan Kesehatan Jiwa dan Psikiatrik. Edisi 3. Jakarta: E GC.

Kurniawa, A. 2008. Faktor-Faktor Yang Berhubungan Dengan Tingkat Kecemasan Orang Tua Terkait Hospitalisasi Anak Usia Toddler Di BRSD RAA Soewondo Pati. Penelitian. http://digilib.unimus.ac.id. Diakses pada 23 September 2007.

National Safety Council .2003. Manajemen Stress. Jakarta: EGC.

Notoatmodjo, S. 2003. Ilmu Kesehatan Masyarakat. Jakarta: Rineka Cipta.

Notoatmodjo, S. 2003. Pendidikan dan Perilaku Kesehatan. Jakarta: Rineka Cipta.

Notoatmodjo, S. 2005. Metodologi Penelitian Kesehatan. Jakarta: Rineka Cipta.

Nursalam. 2003. Konsep dan Penerapan Metodologi Penelitian Ilmu Keperawatan. Jakarta: Salemba Medika.

Pujiastutik. 2008. Tingkat Kecemasan Orang Tua Terhadap Anak Yang Mengalami Hospitalisasi Di Ruang Mawar Rsi 
Gondanglegi Malang. Karya Tulis Ilmiah. Tidak dipublikasikan.

Rahmawati. 2008. Hubungan Dukungan Keluarga dengan Tingkat Kecemasan Akibat Hospitalisasi Pada Anak Usia Pra Sekolah di Bangsal L RSUP Dr. Soeradji Tirtonegoro Klaten, http:skripsistikes.wordpress.com. Diakses pada 23 September 2007.

Sacharin. 1996. Prinsip Keperawatan Pediatrik. Edisi 2. Jakarta: EGC.

Soetjiningsih. 1995. Tumbuh Kembang Anak. Jakarta: EGC.

Stevens, P.J.M. 1999. Ilmu Keperawatan. Edisi 2. Jakarta: EGC.

Sundeen \& Stuart. 1998. Buku Saku Keperawatan Jiwa. Edisi 3. Jakarta: EGC.

Supartini. 2004. Konsep Dasar Keperawatan Anak. Jakarta: EGC.

Tiedeman, M.E. 1997. Anxiety Responses of Parents During and After the Hospitalization of Their 5-to 11-Year-Old Children. Journal of Pediatric Nursing Volume 12. Issue 2. April 1997.

Tomb, M.D. 2004. Buku Saku Psikiatrik. Edisi 6. Jakarta: EGC.

Yakita. 2007. Kecemasan. http// www.Yakita.co.id. Diakses pada 23 September 2007. 